\title{
Holder V. Humanitarian LAW PROJECT: REDEFINING Free SPEech Protection IN THE WAR ON TERror
}

\author{
Aaron Tuley*
}

\section{INTRODUCTION}

Picture a twenty-six-year-old former Army Ranger who returns home from Iraq feeling a little lost, as if he has yet to discover his life's purpose. Let's call this man Pete. Pete enrolls in college upon his return, but then drops out to train as an emergency medical technician. After he completes that training, he decides to restart his collegiate career, but he never graduates. Along the way, he falls in love and gets married, but the marriage ends in divorce a few months later. Then, on a spring break trip, Pete finally finds his calling. Pete travels to Lebanon to use his medical training to assist Syrian refugees. He skips his return flight home to stay and continue providing aid to people who escaped revolution and upheaval. Pete continues providing aid over the following months and he eventually forms an aid organization that provides medical care and aid to anyone who needs it, from refugees to rebels. Now imagine Pete returns to the United States for the holidays, but instead of being greeted by his family and friends, he is met by federal agents who arrest him for providing material support to terrorists. Up until the point of Pete's return home, this was the story of AbdulRahman Peter Kassig before he was captured, held captive, and eventually executed by ISIS. ${ }^{1}$ Had Kassig, who President Obama described as a "humanitarian who worked to save the lives of Syrians injured and dispossessed," 2 been able to return home, his prosecution for providing material support to terrorists would have been entirely possible given the medical aid he provided to terrorists along with refugees. This is just one example of the problems inherent in the statute that prohibits providing material support to terrorists ("Section 2339B"). ${ }^{3}$

The U.S. Supreme Court has had the opportunity to correct at least some of

* J.D. Candidate, 2016, Indiana University Robert H. McKinney School of Law; B.S., 2011, Indiana University, Bloomington, Indiana; B.A., 2011, Indiana University, Bloomington, Indiana. I would like to offer my heartfelt gratitude to my family and friends, especially my parents, Dan and Karen, and brother, Heath, for their unending support and encouragement. I would also like to thank Professor Shawn Boyne and the numerous editors of the Indiana Law Review for their insightful comments and feedback throughout the note writing process.

1. Brian Eason, Indy Native Kassig Was 'Destined for Great Things,' IndianAPOLIS STAR (Nov. 17, 2014), http://www.indystar.com/story/news/2014/11/16/indy-native-kassig-destinedgreat-things/19146169/ [http://perma.cc/8ZE6-CMQA]; Amy Davidson, The Mystery of AbdulRahman, or Peter Kassig, New YorKer (Nov. 17, 2014), http://www.newyorker.com/news/amydavidson/mystery-abdul-rahman-peter-kassig [http://perma.cc/9UEY-2YN2].

2. Press Release, The White House, Statement by the President on the Death of AbdulRahman Kassig (Nov. 16, 2014), available at http://www.whitehouse.gov/the-press-office/2014/ 11/16/statement-president-death-abdul-rahman-kassig [http://perma.cc/3NVZ-6X7H].

3. 18 U.S.C. $§ 2339 B$ (2012); see infra Part I. 
Section 2339B's problems but has so far failed to do so. In Holder v. Humanitarian Law Project, ${ }^{4}$ the Supreme Court incorrectly held that Section 2339B did not violate the First Amendment, thereby narrowing the scope of the First Amendment's protections for freedom of speech. ${ }^{5}$ Congress or the Supreme Court must act to remedy free speech case law and protect the First Amendment.

When the Supreme Court granted certiorari in Humanitarian Law Project, it had the opportunity to protect the First Amendment from encroachment while simultaneously protecting Americans from acts of terror. ${ }^{6}$ At first glance, some may wonder how often there could be a case with an outcome that would both protect the First Amendment and fight terrorism. Since the beginning of the War on Terror and with it the passing of the USA PATRIOT Act, many Americans undoubtedly believe they live in a world where one must choose between life and liberty (security or First Amendment rights). ${ }^{7}$ However, the Supreme Court had the opportunity in Humanitarian Law Project to find the middle ground and protect both. Unfortunately, only three justices were able to see that middle ground. ${ }^{8}$ The other six justices cobbled together a majority opinion that left lower courts and citizens with unclear, undefined terms and limits on the reach of the statute, improperly applied the strict scrutiny standard of review, ignored relevant First Amendment free speech precedent, and ended up giving people and organizations mirage-like protections from prosecution. ${ }^{9}$ Congress or the Supreme Court needs to act to provide guidance on the undefined terms and correct the mistakes regarding application of the strict scrutiny standard and application of relevant precedent. ${ }^{10}$

Part I of this Note introduces the history behind the enactment of Section 2339B, including its genesis in the 1990s and its transformation during the War on Terror. Part II analyzes the First Amendment right to freedom of speech, including its purpose and history, the standards of scrutiny courts use in reviewing statutes being challenged under it, and how the courts have interpreted its boundaries in cases of national security and in times of war. Part III summarizes the relevant facts, procedural history, and arguments of the majority

\section{561 U.S. 1 (2010).}

5. David Cole, The First Amendment's Borders: The Place of Holder v. Humanitarian Law Project in First Amendment Doctrine, 6 HARV. L. \& PoL'y Rev. 147, 148-49 (2012).

6. See id. at 147-48 (describing prior cases in which courts determined government action violated the First Amendment and how Humanitarian Law Project held differently).

7. See, e.g., Geoffrey R. Stone, Free Speech and National Security, 84 IND. L.J. 939, 953 (2009) (quoting Department of Justice Oversight: Preserving Our Freedoms While Defending Against Terrorism: Hearing Before the S. Comm. on the Judiciary, 107th Cong. 313 (2001) (statement of John D. Ashcroft, Att'y Gen. of the United States)) ("To those ... who scare peaceloving people with phantoms of lost liberty, my message is this: Your tactics only aid terrorists, for they erode our national unity and diminish our resolve. They give ammunition to America's enemies ....").

8. Humanitarian Law Project, 561 U.S. at 40-62 (Breyer, J., dissenting).

9. See infra Part V.

10. See infra Part VI. 
and dissenting opinions of Humanitarian Law Project, the leading Supreme Court case analyzing Section 2339B in light of constitutional concerns. Part IV introduces and analyzes various opinions issued from lower courts after the Supreme Court's decision in Humanitarian Law Project to determine how courts applied this precedent. Part V details a number of shortcomings of the majority opinion in Humanitarian Law Project. Part VI ends this Note with a discussion of potential solutions available to both Congress and the Supreme Court. These potential solutions include integrating additional elements of intent espoused in Justice Breyer's Humanitarian Law Project dissent into the statute, providing guidance on the meaning of the terms "independent" and "coordinated," and applying a modified incitement standard to cases involving First Amendment challenges to the statute.

\section{Statutory Prohibitions on Providing Material SUPPORT TO TERRORISTS}

The current framework that criminalizes providing support to terrorist organizations has evolved as the understanding of what "terrorism" means has evolved. ${ }^{11}$ Historically, when the Supreme Court would reference terrorism, it generally discussed violence that took place by foreign actors in foreign lands, subject to a few isolated exceptions. ${ }^{12}$ However, in the years leading up to and especially after $9 / 11$, terrorism became a more important issue domestically. ${ }^{13}$ This change, and the legal framework that developed to meet the new threat, brought with it unique challenges to safeguarding the lives and liberties of American citizens.

\section{A. The War on Terror and the Need for New Law Enforcement Tools}

Generally, anti-terrorism statutes seek to provide a means for the government to stop terrorists before they complete their planned criminal activity. ${ }^{14}$ Antiterrorism statutes need to be preventative because of the inherent difference between terrorism and "traditional" criminal activities. ${ }^{15}$ Terrorism poses a novel challenge to the traditional system of criminal justice because of some terrorists' commitment to martyrdom, which renders post-commission punishment ineffective.$^{16}$ Further, the ability of terrorists to hide in plain sight amongst the local populace until the moment of attack continues to frustrate law enforcement

11. See Wadie E. Said, Humanitarian Law Project and the Supreme Court's Construction of Terrorism, 2011 BYU L. REV. 1455, 1459-77 (2011) (detailing the Supreme Court's jurisprudence relating to "terrorism" from the early 1900 s to the present day).

12. Id. at 1473-74.

13. Id. at 1482 .

14. Nikolas Abel, United States v. Mehanna, The First Amendment, and Material Support in the War on Terror, 54 B.C. L. REV. 711, 722 (2013).

15. Id. at $722-23,725$.

16. Id. at $722-23$. 
efforts at crime prevention. ${ }^{17}$

Congress responded to the unique challenges posed to law enforcement officers seeking to prevent terrorist activities by passing a statute codified at 18 U.S.C. $§ 2339$ A ("Section 2339A") which aimed to cut off any "material support" terrorists received. ${ }^{18}$ Section 2339A, as amended, prohibits "provid[ing] material support or resources ... knowing or intending that they are to be used in preparation for, or in carrying out, a violation of [various enumerated terrorism-related sections] . . . or attempt[ing] or conspir[ing] to do such an act."19 The statute defines "material support or resources" as "any property, tangible or intangible, or service, including currency or monetary instruments . .. financial services, lodging, training, expert advice or assistance ... personnel (1 or more individuals who may be or include oneself) . . . except medicine or religious materials." 20 The terms "training" and "expert advice or assistance" included within the definition of "material support or resources" are further defined in the statute. ${ }^{21}$ "“Training' means instruction or teaching designed to impart a specific skill, as opposed to general knowledge." "“"Expert advice or assistance' means advice or assistance derived from scientific, technical, or other specialized knowledge." 23

\section{B. Congress Broadens the Prohibition on Providing Material Support to Terrorists}

After the 1995 Oklahoma City bombings, Congress determined that the relatively newly enacted Section 2339A did not go far enough in securing the United States from terrorist activity and stemming the flow of money to terrorist organizations. ${ }^{24}$ Thus, Congress passed the Antiterrorism and Effective Death Penalty Act of 1996 ("AEDPA"). ${ }^{25}$ Although the AEDPA made prosecutions easier under Section 2339A, ${ }^{26}$ the AEDPA also included a new statute that prohibited providing material support to terrorists codified at 18 U.S.C. $\S$ $2339 \mathrm{~B} .{ }^{27}$ With the enactment of AEDPA and subsequent amendment of Section

17. Id. at 725 .

18. Violent Crime Control and Law Enforcement Act of 1994, Pub. L. No. 103-322, 108 Stat. 2002 (codified as amended at 18 U.S.C. $\$ 2339$ A (2012)).

19. 18 U.S.C. $\S 2339$ A(a).

20. Id. $\S 2339 \mathrm{~A}(\mathrm{~b})(1)$.

21. Id. $\S 2339 \mathrm{~A}(\mathrm{~b})(1)-(3)$.

22. Id. $\S 2339 \mathrm{~A}(\mathrm{~b})(2)$.

23. Id. $\S 2339 \mathrm{~A}(\mathrm{~b})(3)$.

24. H.R. REP. No. 104-383, at 43-45 (1995).

25. Antiterrorism and Effective Death Penalty Act of 1996, Pub. L. No. 104-132, 110 Stat. 1255 (1996).

26. Abel, supra note 14, at 727.

27. 18 U.S.C. $\S 2339$ B (Section 2339B was subsequently amended three times to get to the current version: first with Uniting and Strengthening America by Providing Appropriate Tools Required to Intercept and Obstruct Terrorism Act of 2001 (USA PATRIOT Act), Pub. L. No. 107- 
2339B, law enforcement officers and federal prosecutors now had the primary tool they would use in the War on Terror. ${ }^{28}$

Section 2339B prohibits "knowingly provid[ing] material support or resources to a foreign terrorist organization, or attempt[ing] or conspir[ing] to do so." 29 This statute uses the same definition of the term "material support or resources" as Section 2339A..$^{30}$ In defining the required mens rea, Section 2339 B states that "a person must have knowledge that the organization is a designated terrorist organization ... that the organization has engaged or engages in terrorist activity ... or that the organization has engaged or engages in terrorism." ${ }^{31}$ The terms "terrorist organization," "terrorist activity," and "terrorism" included in the mens rea requirement are further defined by Section 2339B or by reference to other statutes. ${ }^{32}$

For an organization to be a terrorist organization for purposes of Section 2339B, it must be so designated by the Secretary of State. ${ }^{33}$ The Secretary of State may make this designation if:

[T]he Secretary finds that (A) the organization is a foreign organization; (B) the organization engages in terrorist activity ( . . . or retains the capability and intent to engage in terrorist activity or terrorism); and (C) the terrorist activity or terrorism of the organization threatens the security of United States nationals or the national security of the United States. $^{34}$

For any activity to constitute "terrorist activity," it must first be either illegal in the place where it was committed or illegal in the United States or any State if it had hypothetically been committed there. ${ }^{35}$ Additionally, it must involve a commission or threat, attempt, or conspiracy to do one of a specific list of acts

56, 115 Stat. 380 (2001); second with the Intelligence Reform and Terrorism Prevention Act of 2004 (IRTPA), Pub. L. No. 108-458, 118 Stat. 3762 (2004); and finally with the Statutory TimePeriods Technical Amendments Act of 2009, Pub. L. 111-116, 123 Stat. 1608 (2009)); see Holder v. Humanitarian Law Project, 561 U.S. 1, 11-13 (2010) (detailing the two amendments that had substantive effects on Section 2339B, the USA PATRIOT Act and IRTPA).

28. Noah Bialostozky, Material Support of Peace? The On-the-Ground Consequences of U.S. and International Material Support of Terrorism Laws and the Need for Greater Legal Precision, 36 YALE J. INT'L L. ONLINE 59, 62 (2011).

29. 18 U.S.C. $\S 2339 \mathrm{~B}(\mathrm{a})(1)$.

30. Id. $\S 2339 \mathrm{~B}(\mathrm{~g})(4)$ ("The term 'material support or resources' has the same meaning given that term in [S] ection 2339A (including the definitions of 'training' and 'expert advice or assistance' in that section.")).

31. Id. $\S 2339 \mathrm{~B}(\mathrm{a})(1)$.

32. $I d$.

33. Id. $\S 2339 \mathrm{~B}(\mathrm{~g})(6)$.

34. 8 U.S.C. § 1189(a)(1) (2012); see also Holder v. Humanitarian Law Project, 561 U.S. 1, 9 (2010) (describing briefly the process surrounding designating an organization as a terrorist organization).

35. Id. § 1182(a)(3)(B)(iii) (2012). 
that includes hijacking, kidnapping, assassination, and using a weapon of mass destruction. $^{36}$

Finally, the statute defines the term "terrorism" rather succinctly as "premeditated, politically motivated violence perpetrated against noncombatant targets by subnational groups or clandestine agents." 37

Both Sections 2339A and 2339B are closely related in that they crossreference each other, rely on each other for definitions, and were passed with similar anti-terrorism goals. ${ }^{38}$ However, by enacting Section 2339B, Congress broadened the scope of the prohibition on providing "material support" to terrorists, making terrorism-related charges easier to bring. ${ }^{39}$ Under Section 2339B, a person just has to attempt, conspire, or actually provide support to a terrorist organization, ${ }^{40}$ while under Section 2339 A a person has to attempt, conspire, or actually provide support to a specific terroristic act ${ }^{41}$ Further, under Section 2339B, a person need only have knowledge (or constructive knowledge $)^{42}$ that his or her support is being provided to a designated terrorist organization or an organization that engages in some type of terrorism. ${ }^{43}$ Under Section 2339A, the person must have an intent to support a terroristic act or more discrete knowledge of the terroristic act he or she is supporting. ${ }^{44}$ Additionally, in response to the need of a broader way to combat terrorism, ${ }^{45}$ "when Congress enacted [Section] 2339B, [it] simultaneously removed an exception that had existed in [Section] 2339A(a) (1994 ed.) for the provision of material support in the form of 'humanitarian assistance to persons not directly involved in' terrorist activity." 46

\section{The First Amendment and Freedom of Speech}

Given the breadth of the statutes that prohibit providing material support to

36. $I d$.

37. 22 U.S.C. $\S 2656 f(d)(2)(2012)$.

38. See Brandon James Smith, Protecting Citizens and their Speech: Balancing National Security and Free Speech when Prosecuting the Material Support of Terrorism, 59 LoY. L. REV. 89, 91-94 (2013) (detailing the similarities and differences between the two sections).

39. Id. at 91-93.

40. 18 U.S.C. $\S 2339 B(a)(1)(2012)$.

41. Id. $\S 2339 \mathrm{~A}(\mathrm{a})$.

42. See Goldberg v. UBS AG, 660 F. Supp. 2d 410, 432-33 (E.D.N.Y. 2009) (holding that a person may be liable under Section 2339B "where support wasn't provided directly to a[] . . . [foreign terrorist organization (FTO)]. Such a circumstance may be found where an entity provides support to an alias or agent of an FTO . . [ [or] where an entity provides money or support to an organization knowing that the ultimate beneficiary is the FTO.").

43. 18 U.S.C. $\S 2339 B(a)(1)$.

44. Id. $\S 2339 \mathrm{~A}(\mathrm{a})$.

45. See H.R. Rep. No. 104-383, at 43 (1995) (discussing the need to enact legislation to increase security in the United States).

46. Holder v. Humanitarian Law Project, 561 U.S. 1, 29 (2010) (citation omitted). 
terrorists, questions have arisen regarding whether the enforcement of those statutes will tread on the freedom of speech guaranteed by the First Amendment. ${ }^{47}$ Although the specific context is new, this is not the first time that First Amendment rights have come under fire by national security interests during times of war. ${ }^{48}$ Thus, courts, the government, defendants, and special interest groups have an abundance of precedent from which they can each draw support for their arguments. The challenge for courts is to match the proper line of cases with current situations. The Supreme Court had this opportunity in Humanitarian Law Project but unfortunately failed to address each issue properly. $^{49}$

\section{A. Purpose and History}

Freedom of speech is considered a fundamental right ${ }^{50}$ and is one of the most important rights afforded by the Constitution. ${ }^{51}$ Generally, freedom of speech protects and encourages the public exchange of ideas necessary for proper selfgovernment. ${ }^{52}$ One of the purposes of the First Amendment has been said to be protection of this "marketplace of ideas." ${ }^{33}$ This freedom to speak without fear of repercussion is "one of the chief distinctions that sets us apart from totalitarian regimes. ${ }^{54}$ Courts interpret the First Amendment to protect not only the spoken word but also the conveyance of ideas more broadly. ${ }^{55}$ The Supreme Court showed the expansiveness of this fundamental right in Griswold v. Connecticut ${ }^{56}$ when it stated that the First Amendment included "the right to receive, the right to read and freedom of inquiry, freedom of thought, and freedom to teach-indeed, the freedom of the entire university community." ${ }^{\prime 57}$ Further, speech may be protected from governmental regulation even if its message "stirs people to anger." ${ }^{58}$ Although the freedom of speech is expansive, its protection is not all-encompassing. ${ }^{59}$ The prototypical example of speech that would not be

47. Abel, supra note 14, at 721 .

48. See id. at 715-17 (describing various First Amendment freedom of speech challenges brought during World War I and the Cold War).

49. See infra Parts III-IV.

50. See, e.g., De Jonge v. Oregon, 299 U.S. 353, 364 (1937).

51. See Terminiello v. City of Chicago, 337 U.S. 1, 4 (1949) (describing the necessity of free discussion).

52. Id.

53. Red Lion Broad. Co. v. Fed. Commc'ns Comm'n, 395 U.S. 367, 390 (1969).

54. Terminiello, 337 U.S. at 4.

55. Stanley v. Georgia, 394 U.S. 557, 564 (1969).

56. 381 U.S. 479 (1965).

57. $I d$. at 482 (citations omitted).

58. Terminiello, 337 U.S. at 4.

59. See Andrew V. Moshirnia, Valuing Speech and Open Source Intelligence in the Face of Judicial Deference, 4 HARV. NAT'L SEC. J. 385, 428 (2013) (describing how the First Amendment does not offer protection to certain speech activities including "obscenity, defamation, fraud, 
protected by the First Amendment is shouting "Fire!" in a crowded theater when there is no fire. ${ }^{60}$

\section{B. Standards of Scrutiny and the Content/Conduct Distinction}

When faced with government action that allegedly restricts free speech, courts apply one of the following three tests to determine if the restriction comports with the First Amendment: strict scrutiny, intermediate scrutiny, and rational basis. ${ }^{61}$ In determining which test to apply, courts will look to whether the action regulates speech based on the conduct involved or the content of the message being disseminated. ${ }^{62}$ Conduct-based speech occurs when a person intends to express an idea through his or her conduct. ${ }^{63}$ An example of a conductbased restriction can be found in United States $v$. O'Brien ${ }^{64}$ There, a prohibition on destroying draft cards was in place and O'Brien was prosecuted for burning his draft card as a form of protest against the draft. ${ }^{65}$ Content-based speech, on the other hand, occurs when a person intends to express an idea through a form of communicative expression, such as the spoken or written word ${ }^{66}$ An example of content-based speech is the message conveyed by the words printed on a jacket. ${ }^{67}$ After determining whether the governmental action restricts speech based on conduct or content, the court may then use the proper level of scrutiny to address the First Amendment issues. ${ }^{68}$

Strict scrutiny, which is also referred to by other names such as "a more demanding standard," is generally used when the regulation of speech is contentbased. ${ }^{69}$ Strict scrutiny requires that the statute, regulation, or action be narrowly tailored to address a compelling governmental interest. ${ }^{70}$ Strict scrutiny is the highest level of scrutiny applied and has been described as " strict' in theory and fatal in fact." ${ }^{\text {"71 }}$ Although the basic premise that a minority of actions or

incitement, and speech integral to criminal conduct").

60. Schenck v. United States, 249 U.S. 47, 52 (1919).

61. Abel, supra note 14, at 717-19. The rational basis test is rarely used in the First Amendment freedom of speech context and thus it is only introduced in this Note. Id. at 718 .

62. See, e.g., Holder v. Humanitarian Law Project, 561 U.S. 1, 25-28 (2010) (analyzing whether Section $2339 \mathrm{~B}$ as applied to the plaintiffs regulated their speech based on content or conduct).

63. United States v. O’Brien, 391 U.S. 367, 376 (1968).

64. Id.

65. Id. at 369-370.

66. Humanitarian Law Project, 561 U.S. at 28.

67. Cohen v. California, 403 U.S. 15, 16-18 (1971).

68. Abel, supra note 14, at 717-19.

69. Humanitarian Law Project, 561 U.S. at 28.

70. See, e.g., Ark. Writers' Project, Inc. v. Ragland, 481 U.S. 221, 231 (1987).

71. Gerald Gunther, The Supreme Court, 1971 Term-Foreword: In Search of Evolving Doctrine on a Changing Court: A Model for a Newer Equal Protection, 86 HARV. L. REV. 1, 8 (1972). 
regulations survive strict scrutiny still holds true, this type of extreme characterization of strict scrutiny has been criticized. ${ }^{72}$ The Supreme Court itself stated that it "wish[ed] to dispel the notion that strict scrutiny is strict in theory, but fatal in fact." "' Intermediate scrutiny is used when the regulation is a conductbased restriction on speech. ${ }^{74}$ Intermediate scrutiny in the context of freedom of speech requires that the statute, regulation, or action "advance[] important governmental interests unrelated to the suppression of free speech ... [without] burden[ing] substantially more speech than necessary to further those interests." 75

\section{Applied in Wartime}

Historically, First Amendment protections suffer during times of war due to the Supreme Court's deference to the government's war efforts. ${ }^{76}$ The Court has given various rationales for this increased deference but most may be generally described as relating to the depth of experience held by the executive and legislative branches on matters of national security and foreign affairs. ${ }^{77}$ During World War I, the government convicted individuals for criticizing the war effort pursuant to the Espionage Act ${ }^{78}$ which allowed prosecutions for causing insubordination in the military or hindering recruitment for and enlistment in the armed forces. ${ }^{79}$ The Supreme Court upheld many of these convictions in the face of First Amendment challenges. ${ }^{80}$ During World War II, the Supreme Court upheld various measures taken by the U.S. military, which systematically stepped on the constitutional rights of individuals with Japanese heritage based on the Court's position of deference to the executive and legislative branches in times of war. ${ }^{81}$ During the Cold War, the Supreme Court upheld a conviction based upon speech that supported a communist overthrow of the U.S. government against First Amendment challenges. ${ }^{82}$ Although the Supreme Court has noticeably deferred to the government's expertise in times of war or in matters

72. Adarand Constructors, Inc. v. Pena, 515 U.S. 200, 237 (1995).

73. Id. (internal quotation marks omitted).

74. Humanitarian Law Project, 561 U.S. at 25-27.

75. Turner Broad. Sys., Inc. v. Fed. Commc'ns Comm'n, 520 U.S. 180, 189 (1997) (citing United States v. O'Brien, 391 U.S. 367, 377 (1968)); see also Ashutosh Bhagwat, The Test that Ate Everything: Intermediate Scrutiny in First Amendment Jurisprudence, 2007 U. ILL. L. REV. 783, 801 (describing the requirements of intermediate scrutiny in similar terms).

76. Abel, supra note 14 , at 715-17.

77. Humanitarian Law Project, 561 U.S. at 33-36.

78. 18 U.S.C. $\S \S 792-799$ (2012).

79. Abel, supra note 14, at 715 .

80. See id. at 715-16 (discussing Debs v. United States, 249 U.S. 211 (1919); Frohwerk v. United States, 249 U.S. 204 (1919); Schenck v. United States, 249 U.S. 47 (1919)).

81. See Moshirnia, supra note 59, at 420-21 (discussing Korematsu v. United States, 323 U.S. 214 (1944); Hirabayashi v. United States, 320 U.S. 81 (1943)).

82. See Abel, supra note 14, at 716-17 (discussing Dennis v. United States, 341 U.S. 494 (1951)). 
of national security in First Amendment challenges to government action, the Court has occasionally found that the government did in fact violate the First Amendment. ${ }^{83}$

\section{The Supreme Court Speaks: Holder V. Humanitarian Law Project}

The leading case involving the material support statute and the freedom of speech is Holder v. Humanitarian Law Project. ${ }^{84}$ Chief Justice Roberts delivered the majority opinion ${ }^{85}$ holding that the material support statute did not violate the plaintiffs' freedom of speech or freedom of association under the First Amendment nor did it not violate the Due Process Clause of the Fifth Amendment. ${ }^{86}$ The majority's holding roused a strong dissent from Justice Breyer, which Justices Ginsburg and Sotomayor joined. ${ }^{87}$ The concerns Justice Breyer expressed with the majority's holding and its effect on individuals' First Amendment freedom of speech persist today and must be addressed.

\section{A. Facts and History}

The lead plaintiff in the case was the Humanitarian Law Project ("HLP"). ${ }^{88}$ HLP was a non-governmental organization recognized with consultative status to the United Nations that focused its work on human rights. ${ }^{89}$ Two U.S. citizens were also named as plaintiffs: Ralph Fertig, president of HLP and a former Administrative Law Judge, and Nagalingam Jeyalingam, a naturalized U.S. citizen born in Sri Lanka of Tamil descent. ${ }^{90}$ Additionally, five domestic nonprofit groups focused on advancing the interests of people of Tamil descent were included as plaintiffs. ${ }^{91}$ The plaintiffs sought pre-enforcement review of the material support statute $^{92}$ because they feared that by conducting certain humanitarian work, they would face criminal prosecution under the statute. ${ }^{93}$

At the outset of the litigation, there were two groups of plaintiffs - those who wanted to work with a certain group of Tamils in Sri Lanka and those who wanted to work with a certain group of Kurds in Turkey, which included HLP. ${ }^{94}$ The plaintiffs whose focus was the group of Tamils in Sri Lanka were effectively

83. See generally N.Y. Times Co. v. United States, 403 U.S. 713 (1971) (holding national security concerns did not outweigh the newspaper's free speech interest in publishing classified Defense Department documents).

84. 561 U.S. 1 (2010).

85. Id. at 6 .

86. Id. at 14 .

87. Id. at 40 (Breyer, J., dissenting).

88. Id. at 15 (majority opinion).

89. Id. at 10 .

90. Id.

91. Id.

92. Id. at 15.

93. Id. at 10 .

94. Id. at 14-15. 
removed from the litigation by the time of oral arguments at the U.S. Supreme Court. ${ }^{95}$ These plaintiffs wanted to provide support such as education, legal training, and political advocacy to the humanitarian and political portions of the Liberation Tigers of Tamil Eelam ("LTTE" or "Tamil Tigers"). ${ }^{96}$ The goal of the LTTE was to "establish an independent Tamil state in Sri Lanka," resulted in the group's designation as a Foreign Terrorist Organization ("FTO") by the U.S. Secretary of State. ${ }^{98}$ The LTTE was largely defeated by Sri Lankan government forces during the course of the litigation of this case, ${ }^{99}$ so that the arguments by these plaintiffs related to its activities with the LTTE were rendered moot. ${ }^{100}$ Thus, the Supreme Court focused on the arguments of the other group of plaintiffs led by HLP focusing on the Kurds in Turkey (hereafter collectively referred to simply as HLP). ${ }^{10}$

Prior to the enactment of Section 2339B, HLP worked with the Kurdistan Workers' Party ("PKK") in Turkey in an effort to help it end its disputes with the Turkish government via legal, nonviolent methods. ${ }^{102}$ One of the goals of the PKK is to establish an independent Kurdish state, ${ }^{103}$ which resulted in the U.S. Secretary of State designating the group as a FTO. ${ }^{104}$ HLP previously worked with the PKK in teaching its members how to file and actually filing human rights complaints with the United Nations. ${ }^{105}$ HLP also helped with peace talks between the Turkish government and the PKK and in general advocacy of Kurdish human rights alongside the PKK. ${ }^{106}$ HLP wanted to continue providing similar "legal training and political advocacy."107

In the Ninth Circuit Court of Appeals, ${ }^{108}$ HLP argued that Section 2339B was overbroad in violation of the First Amendment, Section 2339B would violate due process if it was not interpreted to require a specific intent to further the illegal activities of the organization, and certain terms of Section 2339B were unconstitutionally vague. ${ }^{109}$ The Ninth Circuit rejected HLP's First Amendment

95. Id. at 15 .

96. Id.; Moshirnia, supra note 59, at 414 n.163.

97. Moshirnia, supra note 59, at 414 n.163.

98. Designation of Foreign Terrorist Organizations, 62 Fed. Reg. 52,650 (Oct. 8, 1997).

99. Roland Buerk, Tamil Tigers 'Defeated' Says Army, BBC News (June 30, 2008, 4:16

PM), http://news.bbc.co.uk/2/hi/south_asia/7481812.stm [http://perma.cc/7QXN-4RFW].

100. Humanitarian Law Project, 561 U.S. at 15.

101. Id.

102. Id. at 14-15.

103. Moshirnia, supra note 59, at 414 n.163.

104. Designation of Foreign Terrorist Organizations, 62 Fed. Reg. 52,650 (Oct. 8, 1997).

105. Cole, supra note 5, at 151.

106. Id.

107. Humanitarian Law Project, 561 U.S. at 10.

108. The history of the litigation prior to arriving in the Ninth Circuit for the last time is quite lengthy and involves multiple amendments to the statute, appeals, and remands. See id. at 10-14 (summarizing the procedural history of the case).

109. Id. at 13-14 (citing Humanitarian Law Project v. Mukasey, 552 F.3d 916, 926-27, 929-33 
argument, due process argument, and the as-applied vagueness challenge to the term "personnel." " However, that court found that the terms "training," "expert advice or assistance" (related to "other specialized knowledge"), and "service" found in Section 2339B were unconstitutionally vague as applied to HLP. ${ }^{111}$

Both parties filed petitions for certiorari to the U.S. Supreme Court, which the Court granted. ${ }^{112}$ HLP brought two challenges under the First Amendment and one challenge under the Fifth Amendment. ${ }^{113}$ HLP's First Amendment challenges were that Section 2339B violated their freedom of speech and freedom of association. ${ }^{114}$ HLP's Fifth Amendment challenge was that Section 2339B violated the Due Process Clause because the terms "personnel," "training," "expert advice or assistance" (related to "other specialized knowledge"), and "service" were impermissibly vague. ${ }^{115}$ To the extent that the three arguments are separable, this Note focuses on the arguments related to the First Amendment freedom of speech challenge.

\section{B. Majority Opinion}

In the majority opinion, the Court rejected all of HLP's challenges to Section 2339B, including their First Amendment freedom of speech challenge. ${ }^{116}$ Generally, as the statute relates to the freedom of speech, the Court stated that in enacting the statute Congress did not aim to suppress "pure political speech" conveying ideas or opinions. ${ }^{117}$ The Court explained that Congress only sought to stop material support to terrorist organizations and that material support usually does not involve speech. ${ }^{118}$ When material support does involve speech, the Court offered, Section 2339B is "carefully drawn to cover only a narrow category of speech to, under the direction of, or in coordination with foreign groups that the speaker knows to be terrorist organizations." 119

The majority began its analysis by rejecting HLP's proposed reading of Section 2339B that included the heightened mens rea requirement of intent by the defendant to further the illegal activities of a foreign terrorist organization. ${ }^{120}$ HLP argued that this interpretation of the statute was within the statutory requirements and would avoid any potential constitutional issues. ${ }^{121}$ HLP relied

(9th Cir. 2009)).

110. Id. (citing Mukasey, 552 F.3d at 926-27, 929-33).

111. $I d$.

112. Humanitarian Law Project, 561 U.S. at 14.

113. Id.

114. $I d$.

115. Id.

116. Id. at 7 .

117. Id. at 26 .

118. Id.

119. Id.

120. Id. at 16 .

121. Id. 
on Scales v. United States ${ }^{122}$ in which the Court held that the Smith Act, which made membership in a group aimed at overthrowing the government by violent means illegal, required both knowledge of any such group's illegal message and an intent to further that message with action. ${ }^{123}$ The Court stated that HLP's reliance on Scales was misplaced because, unlike in Scales, the statute in question here did not criminalize mere membership in an organization but only criminalized providing material support. ${ }^{124}$ In directly rejecting HLP's proposed interpretation, the Court reasoned that Congress expressly rejected a heightened mens rea requirement. ${ }^{125}$ First, Congress included knowledge as a requirement rather than intent. ${ }^{126}$ Furthermore, the related statutory sections surrounding Section 2339B contain requirements of an intent to further the organization's terrorist activity. ${ }^{127}$ The Court reasoned that if Congress wanted a heightened intent requirement for Section 2339B, it would have included one when it initially enacted the statute or with a subsequent amendment. ${ }^{128}$ The Court continued that as a result of HLP's apparently misplaced reliance on Scales and congressional intent, it did not have any option but to address the constitutional issues raised directly. ${ }^{129}$

In analyzing HLP's freedom of speech argument, the majority first concluded that Section 2339B was a content-based regulation of speech and, as a result, it had to be reviewed under "more rigorous scrutiny" or "more demanding scrutiny," also known as strict scrutiny. ${ }^{130}$ Section 2339B was subject to this heightened scrutiny because it would affect the plaintiffs based on the message of their speech activities. ${ }^{131}$ Thus, the majority analyzed Section 2339B to see if it was narrowly tailored to address a compelling governmental interest. ${ }^{132}$

The Court held that the statute advanced a compelling governmental interest, namely national security. ${ }^{133}$ The Court relied on a statement by Congress that foreign terrorist organizations are completely tainted so a contribution of any kind would help further their illegal activities. ${ }^{134}$ HLP argued that the

122. 367 U.S. 203 (1961).

123. Humanitarian Law Project, 561 U.S. at 17-18.

124. $I d$.

125. Id. at $16-17$.

126. Id.

127. Id. at 17 .

128. Id.

129. Id. at 18 .

130. Id. at 28 .

131. Id. at 27-28 (citing Cohen v. California, 403 U.S. 15 (1971)).

132. See, e.g., Ark. Writers' Project, Inc. v. Ragland, 481 U.S. 221, 231 (1987).

133. Humanitarian Law Project, 561 U.S. at 28 ("Everyone agrees that the Government's interest in combating terrorism is an urgent objective of the highest order.").

134. Id. at 29 (quoting Antiterrorism and Effective Death Penalty Act of 1996, Pub. L. No. 104-132, 110 Stat. $1255 \S 301$ (a)(7) (1996)) ("Foreign organizations that engage in terrorist activity are so tainted by their criminal conduct that any contribution to such an organization facilitates that conduct.") (emphasis by Court). 
"contributions" Congress referred to in the statute pertained only to monetary contributions. ${ }^{135}$ The Court rejected that interpretation by pointing to a provision of the enactment of 2339B that removed an exception in a related material support statute, Section 2339A, for humanitarian aid to people who were not directly involved in any terrorist activities. ${ }^{136}$ The Court also relied on a statement from the State Department which supported the congressional finding that any contribution to a foreign terrorist organization should be prohibited because all facets of those organizations are completely tainted by the terroristic activities. ${ }^{137}$ The Court stated that it was not blindly accepting the rationales put forth by Congress and the executive branch, ${ }^{138}$ but it ultimately deferred to the expertise of those branches in the national security realm. ${ }^{139}$

Next, the majority held that the statute was narrowly tailored in its method of advancing the government's interest. ${ }^{140}$ However, it did not state this conclusion with the same clarity as the conclusion that the statute advanced a compelling governmental interest. ${ }^{141}$ The majority looked favorably upon Congress's prior attempts to clarify the statute with amendments in the face of potential constitutional concerns. ${ }^{142}$ Congress also displayed a desire for the statute to operate within the requirements of the First Amendment by including a provision in the statute itself to that effect. ${ }^{143}$ The majority further reasoned that the statute was narrowly drawn because it only applied to organizations designated as FTOs by the U.S. Secretary of State and any organization deemed an FTO could seek judicial review of the determination. ${ }^{144}$ Finally, the Court found it telling that the statute only purported to apply to activities "directed to, coordinated with, or controlled by foreign terrorist groups" and not any independent advocacy. ${ }^{145}$

The Court's analysis of HLP's vagueness challenges also has First Amendment freedom of speech implications. The Court relied heavily on the provision of Section 2339B that exempted independent acts ${ }^{146}$ in evaluating the

135. Id.

136. Id.

137. Id. at 33 .

138. Id. at 34 ("[T]he Government's authority and expertise in these matters do not automatically trump the Court's own obligation to secure the protection that the Constitution grants to individuals. But when it comes to collecting evidence and drawing factual inferences in this area, the lack of competence on the part of the courts is marked, and respect for the Government's conclusions is appropriate.") (internal citations omitted).

139. Id. at 33-38.

140. Id. at 35-37.

141. See Moshirnia, supra note 59, at 417-20 (arguing that the majority failed to even mention narrow tailoring).

142. Humanitarian Law Project, 561 U.S. at 35-36.

143. Id.

144. Id. at 35 .

145. Id. at 36 .

146. Although the provision itself only refers to general acts, the Court consistently refers to 
clarity of the challenged terms. ${ }^{147}$ The Court repeatedly stated that "independent advocacy . . . is not prohibited by [Section] 2339B." ${ }^{148}$ The majority stated that the statute prohibited activity that is generally coordinated with the FTO. ${ }^{149}$ However, the Court refused to draw a definitive line between what constitutes independent advocacy as opposed to coordinated activity as it "would require "sheer speculation" in this pre-enforcement challenge. ${ }^{150}$ The Court ended its discussion of the difference in these two terms by stating that the "adjudication of the reach and constitutionality of the statute must await a concrete fact situation." $" 151$

The majority concluded by attempting to limit the scope and precedential value of its holding. ${ }^{152}$ It purported that its holding was narrowly directed at the application of the statute to the specific activities that the plaintiffs wanted to do and did not address "more difficult cases" that could come up under Section 2339B. ${ }^{153}$ In dicta, the Court stated that the statute could be open to First Amendment challenges if it were ever used to regulate independent advocacy or domestic organizations. ${ }^{154}$

In the end, the Court rejected each of HLP's First Amendment freedom of speech arguments. ${ }^{155}$ It did this by improper application of the strict scrutiny standard, lack of adherence to applicable precedent, inconsistent application of legislative history, and inconsistent reasoning. ${ }^{156}$ Although it attempted to limit the effect of its decision in dicta and conclusory statements regarding the decision's scope, the Court left in its wake a statute with undefined terms subject to manipulation and an expansive scope that treads on freedom of speech territory. ${ }^{157}$

\section{Justice Breyer's Dissent}

The majority opinion in Humanitarian Law Project drew a sharp dissent written by Justice Breyer and joined by Justices Ginsburg and Sotomayor. ${ }^{158}$ The dissent not only disagreed with the ultimate outcome of the majority but also

it as independent advocacy. Id. at 23-25; 18 U.S.C. $§ 2339 \mathrm{~B}(\mathrm{~h})$ (2012).

147. Humanitarian Law Project, 561 U.S. at 23-25.

148. Id. at 24 .

149. Id. at 23-24 (describing the type of prohibited activity in various terms including that which is "under that terrorist organization's direction or control" or "performed in coordination with, or at the direction of, a foreign terrorist organization").

150. Id. at 25 .

151. Id. (citation omitted).

152. Id. at 39 .

153. Id. at 8 .

154. Id. at 39 .

155. Id.

156. See infra Part V (describing in detail the shortcomings of Humanitarian Law Project).

157. Id.

158. Humanitarian Law Project, 561 U.S. at 40 (Breyer, J., dissenting). 
with some of its basic conclusions and application of the relevant legal principles to the facts at hand. ${ }^{159}$ Justice Breyer interpreted Section 2339B to include a requirement of intent to further the illegal ends of the organization, as advocated by HLP. ${ }^{160}$ Although Justice Breyer's interpretation of the statute avoided any constitutional issues in the litigation, his dissent continued and analyzed the majority's holding that the statute survived strict scrutiny. ${ }^{161}$ Justice Breyer agreed that the relevant standard of inquiry was strict scrutiny and, under that standard, national security was a compelling governmental interest advanced by the statute. ${ }^{162}$ However, under Justice Breyer's reasoning, the statute was not narrowly tailored to that governmental interest. ${ }^{163}$ Further, Justice Breyer took issue with the majority's lack of adherence to relevant precedent. ${ }^{164}$

Justice Breyer read Section 2339B to prohibit protected speech "when the defendant knows or intends that those activities will assist the organization's unlawful terrorist actions." 165 This reading added two related elements to the majority's reading of the statute: intent and knowledge or intent that the support provided helps advance terroristic activity. ${ }^{166}$ These requirements would avoid the constitutional issues that the majority was forced to grapple with, which is generally preferred. ${ }^{167}$ Speech activities normally protected by the First Amendment would continue to be protected, while speech that was knowingly or intentionally communicated to a terrorist organization to support their terrorist activities would rightly not be protected. ${ }^{168}$ According to Justice Breyer, this reading, while not included explicitly in the statute itself, was supported by the statute. ${ }^{169}$ He concluded that the inclusion of the word "material" in the statute meant that the support must be "of real importance or great consequence" because this was the only reasonable definition of the word "material" in context. ${ }^{170}$ Only support given to a terrorist organization that is likely to further its terrorist activities is "of real importance or great consequence" and thus material support under the statute. ${ }^{171}$ According to Justice Breyer, any other reading of the statute would not be consistent with the text of the statute. ${ }^{172}$ Moreover, the statute contained an express provision that it should not be interpreted or applied to conflict with the protections of the First Amendment,

159. Id. at 40-62.

160. Id. at 56 .

161. Id. at 42-55.

162. Id. at $45-46$.

163. Id. at 46 .

164. Id. at 50-52.

165. Id. at 56 (emphasis added).

166. $I d$.

167. Id. at 60 .

168. Id. at 56-57 (citing Brandenburg v. Ohio, 395 U.S. 444 (1969)).

169. Id. at 57-58.

170. Id. (citing Material, Webster's ThiRd New InT'L Dictionary (1961)).

171. Id.

172. Id. (focusing on the definition of the word "material" and its context within the statute). 
which supported this reading of the statute that avoids the First Amendment issues ${ }^{173}$ Justice Breyer further bolstered his interpretation of the statute by citing its legislative history. ${ }^{174}$ Congress passed the statute mainly to stop the movement of money or goods to terrorist organizations and it only intended a limited amount of speech activity to fall within the statute's scope. ${ }^{175}$ Justice Breyer concluded by stating that this reading of Section 2339B "interprets but does not significantly add to what the statute otherwise contains." "176

Although Justice Breyer's reading of Section 2339B would have ended the litigation before any constitutional issues were addressed, he continued his analysis of the majority opinion, which accepted many of the government's arguments and reasoned that the majority incorrectly held that the statute was narrowly tailored. ${ }^{177}$ The government offered two arguments in support of its claim that the statute was narrowly tailored to the compelling interest of national security. ${ }^{178}$ First, the government argued that the speech activities contemplated in the litigation were fungible in the same way that goods, materials, and other banned support are fungible. ${ }^{179}$ However, Justice Breyer reasoned, it was not obvious how peaceful political advocacy would be fungible in the same way as other banned support, such as monetary contributions and physical supplies. ${ }^{180}$ Without the argument being clearly and obviously true, it was up to the government to back up its assertion with specific evidence, which it failed to do. ${ }^{181}$ Second, the government argued that the type of support contemplated by the statute could be prohibited because it would help legitimize terrorist organizations. ${ }^{182}$ Justice Breyer concluded that this argument did not withstand examination because the statute does not forbid all legitimizing speech. ${ }^{183}$ According to the government, the statute permitted membership in the organizations, meetings with the organizations for discussions, and independent advocacy for the organizations. ${ }^{184}$ However, these activities may legitimize terrorist organizations just as much as the banned activities. ${ }^{185}$ Thus, Justice Breyer concluded that the statute was inconsistent in how it dealt with the legitimizing effect of support because both allowed and prohibited aid may legitimize an organization in the same way. ${ }^{186}$ The lack of narrow tailoring in the

173. Id. at 59; 18 U.S.C. $\S 2339$ B(i) (2012).

174. Humanitarian Law Project, 561 U.S. at 59 (Breyer, J., dissenting).

175. Id.

176. Id. at 60 .

177. Id. at 46 .

178. Id. at 47-50.

179. Id. at 47 .

180. $I d$.

181. Id. at $47-48$.

182. Id. at 49 .

183. Id.

184. Id.

185. Id. at 49-50.

186. Id. 
statute, which the majority's holding allowed to persist, will have a chilling effect on protected speech. ${ }^{187}$

Justice Breyer also pointed out the majority's lack of adherence to relevant First Amendment precedent. ${ }^{188}$ At a basic level, the Court previously recognized that First Amendment protections are not suspended in times of war. ${ }^{189}$ Thus, there is no broad allowance for curtailing the freedom of speech in wartime and the statute must survive constitutional scrutiny on its own merits. ${ }^{190}$ Prior cases show that the First Amendment normally strongly protects the type of speech at issue in the case - a protection which the majority did not apply in its analysis. ${ }^{191}$

Further, even the First Amendment protects speech explicitly advocating illegal activity as long as it is not "directed to inciting or producing imminent lawless action and . . . likely to incite or produce such action." ${ }^{192}$ HLP's proposed speech activities would not rise to the type of speech that would be prohibited as incitement speech since it only sought to advocate for and teach lawful means to achieving political goals. ${ }^{193}$ Justice Breyer also showed that the argument that any support could help legitimize terrorist organizations, which the majority accepted, did not comport with some cases decided during the Cold War, in which the government prosecuted people for their speech activity related to Communist affiliated organizations. ${ }^{194}$ The Court did not accept the same "legitimizing" argument in those cases and instead held that the prosecutions were only constitutional if the person supported the organization's illegal purposes. ${ }^{195}$

In his dissent, Justice Breyer brought to light many weaknesses of the majority's holding. ${ }^{196}$ The majority incorrectly refused to accept a reading of Section 2339B that would have avoided the constitutional issues and which was supported by the statute's text and history. ${ }^{197}$ Further, the majority incorrectly applied the relevant constitutional test and ignored or overlooked applicable precedent. ${ }^{198}$ In light of these issues, Justice Breyer stated that the majority opinion incorrectly upheld the statute and did not give effect to the protections

187. Id. at 50 .

188. Id. at $42-45,50-51$.

189. Id. at 45 (quoting United States v. Robel, 389 U.S. 258, 264 (1967) (citation omitted); Abrams v. United States, 250 U.S. 616, 628 (1919) (Holmes, J., dissenting)).

190. Humanitarian Law Project, 561 U.S. at 44-45.

191. Id. at 42-43 (compiling cases from 1938 to 2010).

192. Id. at 43-44 (emphasis in original) (quoting Brandenburg v. Ohio, 395 U.S. 444, 447 (1969)).

193. Id. at 44 .

194. Id. at 50-51.

195. Id. at 51 .

196. Id. at 40-62.

197. Id. at 56-60 (stating that the majority refused to accept a reading of the statute that the text of the statute and its history supported).

198. Id. at 42-45, 47-51. 
guaranteed in the First Amendment. ${ }^{199}$

\section{Examples of Lower Courts' Application of HUMANITARIAN LAW PROJECT}

After the Supreme Court's decision in Humanitarian Law Project, lower courts throughout the country dealt with cases involving Section 2339B and First Amendment challenges in various ways. ${ }^{200}$ Many courts interpreted Section 2339B and Humanitarian Law Project relatively broadly. ${ }^{201}$ However, some read the decision narrowly and limited its scope. ${ }^{202}$

\section{$A$. United States v. Mehanna}

In United States v. Mehanna, ${ }^{203}$ Tarek Mehanna was convicted of violating Section 2339B, among other criminal statutes. ${ }^{204}$ Mehanna's conviction was based upon evidence that he traveled to Yemen in search of a terrorist training camp and that he translated certain materials from Arabic to English and posted them on a website sympathetic to the jihadist $\mathrm{t}^{205}$ movement. ${ }^{206}$ Mehanna appealed his conviction by arguing that the First Amendment protected his translation activities and the jury may have based his conviction on that protected speech. ${ }^{207}$ The Court of Appeals for the First Circuit held that Mehanna's travel to Yemen in search of terrorist training camps was enough, standing alone, to convict him of the charges and so his appeal based on the First Amendment necessarily failed. ${ }^{208}$ Further, since the district court judge correctly summarized the relevant law concerning Section 2339B and the related First Amendment concerns as stated in Humanitarian Law Project, the First Circuit held the conviction would not be reversed even if there was not sufficient evidence to support the conviction based upon the translations alone. ${ }^{209}$ Thus, although the focus of the evidence in the trial court was on Mehanna's translation activities, ${ }^{210}$ the First

199. Id. at 62 .

200. Compare United States v. Mehanna, 735 F.3d 32 (1st Cir. 2013), cert. denied 135 S. Ct. 49 (2014) (reading § 2339B broadly), with Al Haramain Islamic Found., Inc. v. U.S. Dep't of the Treasury, 686 F.3d 965 (9th Cir. 2012) (reading § 2339B narrowly).

201. See, e.g., Mehanna, 735 F.3d at 32; Weiss v. Nat'l Westminster Bank PLC, 768 F.3d 202 (2d Cir. 2014).

202. See, e.g., Al Haramain Islamic Found., Inc., 686 F.3d at 965.

203. Mehanna, 735 F.3d at 41.

204. Id. at 41-42.

205. The word "jihad" in the context of this case refers to violent jihad. Id. at 41 n.3 ("While 'jihad' is a linguistically protean term that may encompass both violent and nonviolent acts, the record makes clear that the defendant used the term to refer to violent jihad ....”).

206. Id. at 41 .

207. Id. at 47.

208. Id. at 46 .

209. Id. at 49-51.

210. Abel, supra note 14, at 731-736. 
Circuit focused on Mehanna's travel to uphold the general verdict returned by the jury. ${ }^{211}$ Mehanna appealed the First Circuit's decision to the Supreme Court, but his petition for certiorari was denied. ${ }^{212}$

The Mehanna case exemplifies the negative practical implications of Section 2339B and the Supreme Court's decision in Humanitarian Law Project. Since the district court instructed the jury as to the state of the law after Humanitarian Law Project, ${ }^{213}$ it allowed the jury to hear evidence on the arguably protected translation activity rather than just the defendant's travel, which could have influenced the jury's decision. Then, the First Circuit reviewed the case with its hands tied with respect to the First Amendment issues raised by Mehanna because the jury received a "sufficient" recitation of First Amendment law relating to Section 2339B. The Supreme Court's denial of certiorari further exacerbated the problem by setting a precedent that this mode of operation is acceptable. Now, prosecutors may introduce highly prejudicial speech related activities into evidence that the First Amendment arguably protects so long as the court includes a summary of the contested majority opinion in Humanitarian Law Project somewhere in its jury instructions.

\section{$B$. Weiss v. National Westminster Bank PLC}

In Weiss v. National Westminster Bank $P L C,{ }^{214}$ a group of approximately two hundred U.S. nationals or the estates or survivors of deceased U.S. nationals brought a civil suit against National Westminster Bank PLC ("NatWest") seeking damages for an alleged violation of Section 2339B, among other statutes. $^{216}$ The plaintiffs alleged that NatWest violated Section 2339B's prohibition on providing material support or resources to a FTO by maintaining bank accounts and completing funds transfers for the Palestine Relief \& Development Fund ("Interpal"). ${ }^{217}$ The plaintiffs further alleged Interpal provided financial and other material support to Hamas, a designated FTO. ${ }^{218}$ The U.S. Secretary never designated Interpal as a FTO, ${ }^{219}$ but during the time of the alleged acts it was a Specially Designated Global Terrorist as determined by the U.S. Treasury Department Office of Foreign Assets Control due to reports it

211. Mehanna, 735 F.3d at 46.

212. Mehanna v. United States, 135 S. Ct. 49 (2014).

213. Abel, supra note 14 , at 735-736.

214. 768 F.3d 202 (2d Cir. 2014).

215. NatWest is incorporated and headquartered in the United Kingdom and operates as a member of the Royal Bank of Scotland Group. Id. at 205.

216. Id. at 204.

217. $I d$.

218. Id.; see also Foreign Terrorist Organizations, U.S.DEP'T STATE, http://www.state.gov/j/ ct/rls/other/des/123085.htm [http://perma.cc/2SNY-CSUQ] (last visited Oct. 11, 2015) (listing HAMAS as a designated FTO since October 8, 1997).

219. Foreign Terrorist Organizations, supra note 218. 
served as a financial conduit for Hamas. ${ }^{220}$ However, British authorities determined that Interpal was not involved in terror financing. ${ }^{221}$ In short, the plaintiffs argued that NatWest provided material support to Hamas, a FTO, in violation of Section 2339B by allowing Interpal, a non-FTO, to be a banking customer. $^{222}$

The case was appealed to the Second Circuit based on the easily resolved issue of whether the district court applied the incorrect scienter standard. ${ }^{223}$ The district court essentially confused the mens rea requirements of Sections 2339A and 2339B by applying the mens rea requirement of Section 2339A rather than the proper requirement outlined in Section 2339B. ${ }^{224}$ However, the Second Circuit went further than simply resolving this confusion and ended up broadening the scope of Section 2339B. ${ }^{225}$ The court summarized the scienter requirement of Section 2339B by stating, "a defendant has knowledge that an organization engages in terrorist activity if the defendant has actual knowledge of such activity or if the defendant exhibited deliberate indifference to whether the organization engages in such activity." 226 The Second Circuit then held a defendant shows deliberate indifference when it "knows there is a substantial probability that the organization engages in terrorism but . . does not care."227 Thus, rather than imposing liability (either civil or criminal) on a party when it knows the organization with which it is dealing is involved in terrorism, ${ }^{228}$ now a party may be liable under the material support statute when it is substantially likely that the organization is involved in terrorism. ${ }^{22}$ This results in an expansion of the mens rea requirement of Section 2339B from that expressly included in the statute. This case allows the holding in Humanitarian Law Project to be applied in more instances and will only exacerbate the chilling effects of that case in the exercise of the right to free speech.

C. Al Haramain Islamic Foundation, Inc. v. U.S. Department of the Treasury

In Al Haramain Islamic Foundation, Inc. v. United States Department of the Treasury, ${ }^{230}$ the Multicultural Association of Southern Oregon ("MCASO") brought a pre-enforcement action seeking a judgment that it could advocate on

220. Weiss, 768 F.3d at 205.

221. Id. at $205-06$.

222. Id. at 204.

223. Id. at 206 .

224. Id. at 209; see also supra Part I (describing the differences between the mens rea requirements of Sections 2339A and 2339B).

225. See Weiss, 768 F.3d at 206-09 (describing the statutory framework as it interpreted it).

226. Id. at 208 (emphasis added) (citations omitted).

227. Id. (quoting Boim v. Holy Land Found. for Relief \& Dev., 549 F.3d 685, 693 (7th Cir. 2008))

228. 18 U.S.C. $\S 2339 B(a)(1)(2012)$.

229. Weiss, 768 F.3d at 208.

230. 686 F.3d 965 (9th Cir. 2012). 
behalf of and in coordination with Al Haramain Islamic Foundation, Inc. ("AHIF"). ${ }^{231}$ AHIF was an organization incorporated under Oregon law, operating out of Oregon, and with money in domestic banks. ${ }^{232}$ However, AHIF had ties to an international organization with the same name. ${ }^{233}$ Thus, it was somewhat of a hybrid between a domestic and foreign organization. ${ }^{234}$ AHIF had also been designated as a terrorist organization pursuant to Executive Order $13224,{ }^{235}$ which has basically the same effect as being designated as a FTO pursuant to Section 2339B. ${ }^{236}$ Accordingly, the Ninth Circuit analyzed MCASO's First Amendment pre-enforcement challenge under the framework established by Humanitarian Law Project. ${ }^{237}$ The court interpreted the holding in Humanitarian Law Project narrowly and concluded that the content-based prohibition on MCASO's speech activities violated the First Amendment. ${ }^{238}$ The Ninth Circuit differentiated MCASO's challenge from that of the plaintiffs in Humanitarian Law Project by focusing on the facts that AHIF was mainly a domestic organization and that there was a lack of evidence to support any inference that MCASO's speech activity would provide aid to the international AHIF organization. ${ }^{239}$ This case provides more hope than the prior two cases discussed because it shows that at least some courts will refuse an invitation from the government to interpret Humanitarian Law Project any more broadly than it is already written. ${ }^{240}$ If more circuits follow the example set by the Ninth Circuit in narrowly interpreting the holding of Humanitarian Law Project, the problems raised by that case can be mitigated.

\section{Problems with the Court's Current Framework}

\section{A. Undefined Terms}

The Court's current framework of analysis of First Amendment issues in prosecutions of Section 2339B established by Humanitarian Law Project is flawed because it has too many critical undefined terms. The difference between activity that is subject to prosecution under the statute (coordinated activity) and that which is not (independent advocacy) has not been clearly stated. ${ }^{241}$ The

231. Cole, supra note 5, at 175.

232. Al Haramain Islamic Found., Inc., 686 F.3d at 998.

233. Id.

234. Id.

235. Cole, supra note 5, at 174.

236. Al Haramain Islamic Found., Inc., 686 F.3d at 997 ("For purposes of the First Amendment analysis, we see no difference between section 2(a) of EO 13,224 and the statute at issue in [Humanitarian Law Project].”).

237. Id. at $995-1001$.

238. Id. at 1000-01.

239. Id. at 1000 .

240. Cole, supra note 5, at 175.

241. Holder v. Humanitarian Law Project, 561 U.S. 1, 25 (2010). 
Court stated that a determination of the precise line of demarcation between coordinated activity and independent advocacy "must await a concrete factual situation." ${ }^{42}$ However, the Court's recent denial of certiorari in Mehanna and its corresponding implicit approval of a jury instruction summary of Humanitarian Law Project that serves as a cure-all to First Amendment issues, points to the conclusion that a "concrete factual scenario" that would help define the limits of Section 2339B will never survive an appeal to a circuit court of appeals. ${ }^{243}$ Due to this lack of clarity in statutory terms, people will not be free to exercise their rights under the First Amendment fully. ${ }^{24}$

\section{B. Improper Application of the Strict Scrutiny Standard: Not Narrowly Tailored}

Although the majority in Humanitarian Law Project stated that it was applying a "more demanding standard," the strict scrutiny standard, ${ }^{245}$ it did not actually apply it correctly. Under this heightened level of scrutiny, the government must show that the statute both advances a compelling interest and that it is narrowly tailored to advance that interest. ${ }^{246}$ All parties agreed that national security was a compelling governmental interest. ${ }^{247}$ Thus, the improper application of the strict scrutiny standard arose in the majority's analysis of whether the statute was narrowly tailored to advance the compelling interest of national security. ${ }^{248}$ The majority's narrow tailoring analysis was flawed based on the following three issues.

First, the statute is not narrowly tailored because it is underinclusive in certain situations. The statute does not include all speech activity that may serve to "legitimize" a terrorist organization. ${ }^{249}$ The statute prohibits speech activity that is coordinated with an FTO but does not prohibit membership or independent advocacy. ${ }^{250}$ However, almost any speech activity in support of a group will tend to increase its legitimacy, regardless of whether that speech is coordinated with the organization. ${ }^{251}$ Further, independent advocacy for an FTO, which is allowed, may lend even more legitimacy to an organization than any speech that is

242. Id. (internal citation omitted); Moshirnia, supra note 59, at 430-33.

243. See, e.g., United States v. Mehanna, 735 F.3d 32 (1st Cir. 2013), cert. denied 135 S. Ct. 49 (2014).

244. See Humanitarian Law Project, 561 U.S. at 51-52 (Breyer, J., dissenting) ('I am not aware of any form of words that might be used to describe 'coordination' that would not, at a minimum, seriously chill not only the kind of activities the plaintiffs raise before us, but also the 'independent advocacy' the Government purports to permit.").

245. Id. at 28 .

246. See, e.g., Ark. Writers' Project, Inc. v. Ragland, 481 U.S. 221, 231 (1987).

247. Humanitarian Law Project, 561 U.S. at 46 (Breyer, J., dissenting).

248. Id.

249. Id. at 49-50.

250. Id. at 49 .

251. Id. at 50 . 
coordinated with an FTO, which is prohibited. ${ }^{252}$ If one of the true purposes of Section 2339B is to prohibit speech activities which could "legitimize" a designated foreign terrorist organization, it would need to prohibit all speech activities in favor of such an organization. ${ }^{253}$ The fact that the statute does not include such a prohibition is indicative of arbitrary line drawing that should not withstand strict scrutiny.

Second, the statute is not narrowly tailored because it is overinclusive in the scope of who may be ensnared by its wide net. As the statute stands, it could potentially be used to prosecute journalists, academics, or, as clearly shown by Humanitarian Law Project, humanitarian aid groups. ${ }^{254}$ Journalists who were covering a designated foreign terrorist organization, reporting on a conflict involving a designated terrorist organization, or generally assigned to a geographic area controlled or influenced by a designated foreign terrorist organization would likely need to engage in some type of activity that could be seen as "coordinated" with those organizations. ${ }^{255}$ In some instances, journalists may need to obtain permission from a terrorist organization to conduct interviews or travel through its territory. This would necessarily involve some amount of coordination. After this coordination is established, if the article did anything short of outright denouncing the foreign terrorist organization, the journalist may be subject to prosecution under Section 2339B. Additionally, a journalist who wrote an article detailing an FTO's lowering of the price of basic necessities in areas under its control may have provided "material support" for the organization. Likely any article with slight positives about an FTO, any of its missions, or any of its members provides the material support contemplated by the statute after Humanitarian Law Project by allowing the organization to divert resources away from propaganda toward its illegal activities. ${ }^{256} \mathrm{Just}$ as journalists may be prosecuted under the statute, the same may be said for academics that research and publish on terrorist organizations or the areas they control. ${ }^{257}$ Additionally, clearly humanitarian aid organizations cannot provide the same type of training as HLP sought to provide, but, under the current framework, humanitarian organizations may not be able to provide aid to civilians affected by violence and unrest (or may severely limit their operations) in any areas in

252. Id. at 49-52.

253. Id. at 50 .

254. Id. at 7 (majority opinion); Moshirnia, supra note 59, at 433-35.

255. Moshirnia, supra note 59, at 433-35; see also A Bruise on the First Amendment, N.Y. Times, June 21, 2010, at A26, available at http://www.nytimes.com/2010/06/22/opinion/22tue1. html [http://perma.cc/8ELK-RKR9] (describing how academics, journalists, and journalists' sources could all be prosecuted under Section 2339B).

256. Moshirnia, supra note 59, 434-35. The Humanitarian Law Project majority viewed any support provided in any way to an FTO (arguably even unintended support) as material support because it "frees up other resources within the organization that may be put to violent ends."

Humanitarian Law Project, 561 U.S. at 30.

257. Moshirnia, supra note 59, at 433-34. 
which FTOs operate for fear of potential criminal liability. ${ }^{258}$

Finally, the majority in Humanitarian Law Project gave too much deference to the government in coming to its conclusion that the statute was narrowly tailored, which tainted its analysis. The type of scrutiny the court actually applied in Humanitarian Law Project has been called "deferential strict scrutiny." 259 It is not uncommon for the Court to defer to the President and Congress in matters of national security, ${ }^{260}$ but the Court had never before given so much deference to the government in dealing with a First Amendment freedom of speech issue. ${ }^{261}$ Normally, the Court defers to the government only after establishing that there was a factual basis for the government's finding. ${ }^{262}$ Additionally, when dealing with First Amendment freedom of speech issues, the Court typically requires the government's findings to be specific to speech activities. ${ }^{263}$ However, in this case the majority accepted the government's finding that designated terrorist organizations are completely tainted, which precluded not just the contribution of money and goods but also speech activities and the arguments based on that finding without demanding specific evidence. ${ }^{264}$ The majority did this even though there was evidence showing that Congress was only concerned with items such as "funds," "financing," and "goods" when it made its complete tainting finding. ${ }^{265}$ As Justice Breyer concluded in his dissent, the reason that no specific evidence was brought forth regarding speech activities is because none existed that supported the government's specific contention. ${ }^{266}$ Thus, the deference given to the government by the majority was neither typical nor warranted.

The Court's current framework of analyzing First Amendment freedom of speech issues in the context of Section 2339B is flawed due to the misapplication of the strict scrutiny standard in Humanitarian Law Project. This misapplication allowed a criminal framework to persist that was underinclusive, running against the very rationales offered in its support, and overinclusive, allowing the statute to be stretched to unconstitutional lengths against too many people. Further, the Court based its holding upon a finding of Congress that the Court never fully

258. See Cole, supra note 5, at 149 (questioning whether former President Jimmy Carter, former Attorney General Michael Mukasey, former Homeland Security advisor Fran Townsend, and former Secretary of Homeland Security Tom Ridge would be subject to criminal liability for their humanitarian work); see also Maria Abi-Habib, Islamic State Poaches International Aid for Syrians, WALLST.J.(Nov. 17, 2014, 3:40 AM), http://www.wsj.com/articles/islamic-state-poachesinternational-aid-for-syrians-1416158609 [http://perma.cc/7348-SD8M] (describing instances in which the Islamic State has stolen international aid bound for Syrian refugees and used it for its own purposes).

259. Cole, supra note 5, at 158.

260. See, e.g., United States v. Curtiss-Wright Exp. Corp., 299 U.S. 304, 319-20 (1936).

261. Cole, supra note 5, at 158.

262. Id. at $158-59$.

263. Id. at 159-60.

264. Holder v. Humanitarian Law Project, 561 U.S. 1, 47-48 (2010) (Breyer, J., dissenting).

265. Id. at 48 .

266. Id. at 47-48; Cole, supra note 5 at 159-60. 
tested, which resulted in the Supreme Court turning a blind eye to the executive and legislative branches' constraint of the freedom of speech.

\section{Lack of Adherence to Precedent}

The Supreme Court majority ignored relevant First Amendment precedent in rejecting HLP's freedom of speech challenge. Traditionally, courts apply the incitement standard set out in Brandenburg v. Ohio ${ }^{267}$ when speech allegedly advocates violence. ${ }^{268}$ According to Brandenburg, this type of speech is protected unless its goal is to incite "imminent lawless action" and it is likely to achieve that goal. ${ }^{269}$ A possible reason that Brandenburg was not discussed in Humanitarian Law Project is that HLP was not seeking to speak directly about violence but rather wanted to help open peaceful dialogue. ${ }^{270}$ The majority's language attempting to limit the scope of the decision ${ }^{271}$ and the desire to "await a concrete fact situation" 272 may indicate that it expected to be able to address a more traditional incitement issue in a future case involving Section 2339B. However, the Supreme Court's denial of certiorari in recent cases ${ }^{273}$ may indicate that the Court views Humanitarian Law Project as adequate precedent for all cases involving free speech challenges to Section 2339B, even those that could traditionally be analyzed under the incitement standard.

\section{Vi. Potential Solutions}

\section{A. Congressional Amendment}

One possible solution to the issues raised by Section 2339B and Humanitarian Law Project is a congressional amendment to Section 2339B. Given the Supreme Court's recent denials of certiorari and lower courts' treatment of Section 2339B, ${ }^{274}$ an amendment to Section 2339B may be the best option for resolving some of its problems. Congress has shown a willingness to amend Section 2339B in the past ${ }^{275}$ and a humanitarian-related amendment has been introduced in the House of Representatives. ${ }^{276}$ Amending the statute would send a strong and clear message to the courts concerning Congress's intent on the issue. Congress also has the benefit of hindsight in observing how the Supreme Court and lower courts have interpreted Section 2339B and it can use that to

267. 395 U.S. $444,448-49$ (1969).

268. Abel, supra note 14, at 719.

269. Brandenburg, 395 U.S. at 447.

270. Abel, supra note 14, at 742-43.

271. Humanitarian Law Project, 561 U.S. at 8 (majority opinion).

272. Id. at 25 (internal citation omitted).

273. See, e.g., United States v. Mehanna, 735 F.3d 32 (1st Cir. 2013), cert. denied 135 S. Ct. 49 (2014).

274. See, e.g., id.

275. See supra note 27 and accompanying text.

276. Humanitarian Assistance Facilitation Act of 2013, H.R. 3526, 113th Cong. (2013). 
update the statute to create a framework that properly balances freedom of speech and national security concerns.

The best option for a congressional amendment would be to incorporate the interpretation of the statute used in Justice Breyer's dissent. Justice Breyer read Section 2339B to criminalize "First Amendment-protected pure speech . . . only when the defendant knows or intends that those activities will assist the organization's unlawful terrorist actions. "277 This option would be the simplest change to the statute. All that would be needed would be to add another section to the statute detailing the analysis required when a case involves First Amendment activity. This option would also correct the most problems with the current statutory framework. Adding the elements of intent and furtherance of the FTO's unlawful goals eliminates the need to focus on whether the activity was independent of or coordinated with the organization. Using the elements of intent and furtherance would also allow courts to analyze cases using more familiar criminal statutory language than parsing out the differences between coordinated and independent activity. The addition of these elements addresses the issues of narrow tailoring as well. It would bring in more "legitimizing" speech by including speech which has the purpose of lending legitimacy to a FTO rather than focusing on the level of coordination involved in the speech, which does not necessarily correlate with increasing legitimacy. It would also resolve issues concerning liability of journalists reporting on FTOs or academics studying FTOs as long as their purpose was not to support the organization's terrorist activity. Finally, a change of this kind may be substantial enough for the Supreme Court to accept a petition for certiorari and give consideration to the Brandenburg incitement standard ${ }^{278}$ of reviewing speech activity.

Another option for Congress would be to provide some direction as to what activity is independent of a FTO and what activity would be coordinated with a FTO. Congress could either define what independent means for the statute or provide a non-exhaustive list of independent activity. It could define independent activity as activity that is taken without the control or request of a foreign terrorist organization as to the content or conduct of the speech-related activity. A non-exhaustive list of independent activities could include activities such as reporting or researching a foreign terrorist organization without allowing that organization to control the content of the report or research. This option provides some certainty regarding potential prosecutions under Section 2339B for activities that may be considered independent. This increased certainty will help combat the chilling effect the current framework has on free speech. Adding direction as to what constitutes independent activity would also address some of the tailoring problems shown in Section 2339B by Humanitarian Law Project. It would help narrow the scope of the statute to include only those activities truly coordinated with a FTO. However, it would not address the "legitimizing" activity issue as fully as incorporating the language of Justice Breyer's dissent would. Thus, this option, while providing some additional guidance, would not

277. Humanitarian Law Project, 561 U.S. at 56 (Breyer, J., dissenting) (emphasis added).

278. See Brandenburg v. Ohio, 395 U.S. 444, 447 (1969) (describing the incitement standard). 
be as extensive as the first congressional amendment option discussed above.

\section{B. Supreme Court Refinement}

If Congress does not act to amend Section 2339B, the Supreme Court could address some of the problems in the current framework surrounding Section 2339B. However, the Court's recent denials of certiorari ${ }^{279}$ could indicate that the Court either does not see any problems with the current framework or does not think the problems that exist rise to a level warranting consideration. This recent trend of denying certiorari will be the major hurdle to any Supreme Court refinement. Further, unless the Court is prepared to overrule Humanitarian Law Project outright, its options are limited to addressing issues left open in that case.

If the Supreme Court does eventually accept certiorari in a case involving a First Amendment challenge to Section 2339B, it could fully explain the legal difference between independent and coordinated activity. Like Congress, it could attempt to define "independent activity" or provide a non-exhaustive list of example independent activities. Just as if Congress were to take this route, it would address some issues such as the presence of undefined terms and the lack of narrow tailoring due to overinclusiveness. However, if the Supreme Court refined the statutory framework in this manner, its effect would be even more limited than that of a congressional amendment given the potential separation of powers issues that could arise with broad statutory interpretation.

Another option for the Supreme Court would be to change the rules of the game by bringing in the incitement standard from Brandenburg. ${ }^{280}$ Since HLP was not directly advocating taking violent actions, using an incitement standard would not be seen as directly overruling the precedent set in Humanitarian Law Project. Additionally, the language of Section 2339B itself, which prohibits the interpretation of the statute in a way that would reduce First Amendment rights, supports incorporating this First Amendment precedent. ${ }^{281}$ The Court could use Brandenburg as the basis of a new "terrorism incitement standard" that would be specifically tailored to the unique threats of international terrorism. ${ }^{282}$ According to Brandenburg, the First Amendment protects speech advocating violence unless its goal is to incite "imminent lawless action" and it is likely to achieve that goal. ${ }^{283}$ The first requirement could be expanded to include inciting "imminent lawless action" on behalf of a FTO as well as facilitating the provision of material support to an FTO in furtherance of its illegal activities. This would combine the Section 2339B analysis with free speech and incitement jurisprudence in a way that provides some of the traditional safeguards to First Amendment rights while combating terrorism. By incorporating this more traditional First Amendment analysis into the Section 2339B framework, courts

279. See, e.g., United States v. Mehanna, 135 S. Ct. 49 (2014).

280. See Brandenburg, 395 U.S. at 447 (describing the incitement standard).

281. 18 U.S.C. $\S 2339 B(i)$ (2012).

282. See infra Part I.A (describing ways in which terrorism is a unique threat).

283. Brandenburg, 395 U.S. at 447. 
are more likely to analyze cases properly under strict scrutiny and give the government the proper amount of deference.

\section{CONCLUSION}

The Supreme Court's holding in Humanitarian Law Project incorrectly upheld the "material support" statute in the face of First Amendment challenges and, as a result, the protection afforded by the First Amendment's freedom of speech clause has shrunk. The majority opinion improperly applied or outright ignored prior First Amendment precedent, left undefined statutory terms at the core of its holding, and upheld a statutory scheme that has an overly expansive scope. A congressional amendment either incorporating elements of intent and furtherance of a FTO's illegal actions or defining "independent" would provide the most lasting and broad correction to the problems of Section 2339B and Humanitarian Law Project. However, if Congress does not amend the statute, the Supreme Court can step in to clarify the meaning of "independent" or to incorporate First Amendment precedent, even if it does not want to overrule Humanitarian Law Project explicitly. Although the importance of giving law enforcement officials the tools they need to catch terrorists cannot be realistically debated, the tools Congress gives should not allow law enforcement to tread roughshod over First Amendment rights. Ultimately, Congress or the Supreme Court must act to protect the First Amendment and freedom of speech from becoming a casualty in the War on Terror. 